\title{
NOTE
}

\section{LEEDOM v. KYNE AND THE IMPLEMENTATION OF A NATIONAL LABOR POLICY}

Twenty-three years ago, in Leedom v. Kyne, ${ }^{1}$ the United States Supreine Court held that under certain circumstances a federal district court has jurisdiction to set aside a representation order issued by the National Labor Relations Board.2 The Court affirmed the district court's exercise of jurisdiction in Kyne because the Board's representation order exceeded "its delegated powers and [was] contrary to a specific prohibition" 3 in the National Labor Relations Act. ${ }^{4}$ Recently, Chief Judge Wright of the Court of Appeals for the District of Columbia Circuit, in his dissenting opinion in Physicians National House Staff Association v. Fanning, ${ }^{5}$ reformulated the Kyne standard. ${ }^{6}$ He proposed a four-part test to determine district court jurisdiction to review Board representation orders. ${ }^{7}$

Three notable deficiencies in the Kyne standard nake its reformulation appropriate. First, the Kyne standard provides no guidelines to aid courts in determining when statutory niandates ${ }^{8}$ command Board $^{2}$ action. Because Congress and the courts have allowed the Board to

1. 358 U.S. 184 (1958). For a discussion of this case, see notes $66-80$ infra and accompanying text.

2. Id. at 191.

3. Id. at 188. See text accompanying note 76 infra.

4. 29 U.S.C. $\S \S 151-169$ (1976 \& Supp. III 1979).

5. 642 F.2d 492 (D.C. Cir. 1980) (en banc), cert. denied, 101 S. Ct. 1360 (1981). See notes 106-17 infra and accompanying text.

6. Using the term "the Kyne standard" is slightly misleading because the Kyne opinion did not set forth a specific standard to guide lower courts. As a result lower courts lave used various parts of the Kyne holding, see text accompanying note 76 infra, as the Kyne standard. See, e.g., Rockford Redi-Mix Co. v. Zipp. 632 F.2d 30, 31 (7th Cir. 1980) (certification proceeding is reviewable only when a Board order exceeds its jurisdiction and is "contrary to a specific and unambiguous provision of the Act") (footnote oinitted), cert. denied, 101 S. Ct. 1388 (1981); National Maritime Union v. NLRB, 375 F. Supp. 421, 430 (E.D. Pa.) (statutory terms must be "sufficiently 'clear and unandatory' to confer jurisdiction"), affd 506 F.2d 1052 (3d Cir. 1974), cert. denied, 421 U.S. 963 (1975).

7. See text accompanying note 114 infra.

8. An example of a statutory mandate is section $9(\mathrm{c})(1)$ of the Act, 29 U.S.C. $\$ 159(\mathrm{c})(1)$ (1976): "If the Board finds . . that . . a question of representation exists, it shall direct an election...." (emphasis added). 
exercise considerable discretion under statutory mandates, ${ }^{9}$ these provisions, unlike statutory prohibitions, ${ }^{10}$ do not always command Board action. Without clear guidelines courts may incorrectly construe statutory mandates and improperly assume jurisdiction under the Kyne standard, thus infringing the Board's sphere of discretion. ${ }^{11}$ This result impedes the Board's ability to effectively resolve labor disputes. ${ }^{12}$ Second, the Kyne standard fails to address the following, siginificant concern: the denial of district court jurisdiction can result in the absence of judicial review of Board representation orders. ${ }^{13}$ Third, the Kyne standard does not indicate whether district court jurisdiction should be demed to a party who could secure judicial review of a Board order in the courts of appeals after the representation election has occurred.

The significance, in addition to the shortcomings, of the Kyne standard makes its examination worthwhile. Historically, employers, unions, and eniployees have invoked district court jurisdiction to disrupt the representation process. ${ }^{14}$ The $K y n e$ standard determines the frequency of such interruptions, and therefore, in some cases, determines the results of a representation election. As a jurisdictional standard Kyne also determines the relative roles of the courts and the Board in regulating the representation process. Because the Kyne standard is used under numerous regulatory acts, ${ }^{15}$ its significance as an allocating

9. See, e.g., Gould, Inc. v. Fuchs, 486 F. Supp. 164, 168 (D. Conn. 1980); National Maritime Union v. NLRB, 375 F. Supp. 421, $432-34$ (E.D. Pa.), affd 506 F.2d 1052 (3d Cir. 1974), cert. denied, 421 U.S. 963 (1975).

10. Statutory prohibitions forbid certain action. Section 9 (b)(1), 29 U.S.C. $\S 159$ (b)(1) (1976), for example, provides: "[T] sional and nonprofessional employees] is appropriate [unless the] professional employees vote for inclusion in such [a] unit . . . ." (emphasis added).

11. See notes 96-101 infra and accompanying text.

12. Courts should interfere with Board action only if the Board acts clearly in excess of its delegated powers. See NLRB v. Local 103, Int'1 Assoc. of Bridge Workers, 434 U.S. 335, 350 (1978) (quoting NLRB v. Truck Drivers, 353 U.S. 87, 96 (1957)). Justice White, in Local 103, explained the rationale underlying this proposition:

The Board's resolution of the conflicting claims in this case represents a defensible construction of the statute and is entitled to considerable deference. Courts may prefer a different apphication of the relevant sections, but "[t] he function of striking that balance to effectuate national labor policy is often a difficult and delicate responsibility, which the Congress committed primarily to the National Labor Relations Board, subject to limited judicial review."

434 U.S. at 350 (citations omitted).

13. See text accompanying notes $102-05$ infra.

14. See notes 24-28 infra and accompanying text.

15. See, e.g., Borden, Inc. v. FTC, 495 F.2d 785, 786-87 (7th Cir. 1974) (citing Kyne in support of the "well-settled" proposition that district courts should not interfere with agency action unless the agency has clearly violated a right secured by a statute or regulation); United States v. Feaster, 410 F.2d 1354, 1371 (5th Cir.) (applying Kyne to the Railway Labor Act, 45 U.S.C. $\$ \&$ 151-200 (1976 \& Supp. III 1979)), cert. denied, 396 U.S. 962 (1969); Elmo Division of Drive-X Co. v. Dixon, 348 F.2d 342, 343-46 (D.C. Cir. 1965) (Federal Trade Commission Act, 15 U.S.C. 
mechanism between courts and administrative agencies is not limited to the National Labor Relations Act.

This note first examines the Kyne standard and the reformulation suggested in the Physicians dissent. The note then argues that the Kyne test provides madequate jurisdictional guidelines and that the reformulation proposed in Physicians does not effectively resolve these inadequacies. Finally, this note proposes a standard for determining when district court jurisdiction should be exercised to review Board representation orders. ${ }^{16}$

\section{The Representation Process and Judicial Review of REPRESENTATION ORDERS}

\section{A. Background.}

Although courts have cited Leedom v. Kyne in various contexts, ${ }^{17}$ it is invoked most frequently when a union seeks to become the authorized bargaining representative for a group of employees. ${ }^{18}$ Section 9 of

$\$ \S 41-47$ (1976 \& Supp. III 1979)); Marshall v. Nichols, 486 F. Supp. 615, 621 (E.D. Tex. 1980) (Occupational Health and Safety Act, 29 U.S.C. $\$ \S 651-678$ (1976)); M.G. Davis \& Co. v. Cohen, 256 F. Supp. 128, 131 (S.D.N.Y.) (Securities Exchange Act of 1934, 15 U.S.C. $\$ \$ 78 \mathrm{a}-78 \mathrm{kk}$ (1976 \& Supp. III 1979)), affd, 369 F.2d 360 (2d Cir. 1966); Long Island R.R. v. United States, 193 F. Supp. 795, 799-800 (E.D.N.Y. 1961) (Interstate Commerce Act, 49 U.S.C. $\$ \$ 1-40$ (1976 \& Supp. III 1979)); $c$. Associated Builders and Contractors, Inc. v. Irving, 610 F.2d 1221, 1227 (4th Cir. 1979) (Kyne standard applied in reviewing acts of General Counsel), cert. denied, 446 U.S. 965 (1980).

16. This note does not discuss whether district court jurisdiction under $K y n e$ should be eliminated entirely. This judgment belongs to Congress. Nor does this note discuss an interesting paradox: only two judicial forums, the courts of appeals and the Supreine Court, are available to review unfair labor practice orders, see notes 35-40 infra and accoinpanying text; three judicial forums, the district courts, the courts of appeals, and the Supreme Court, are available to review Board representation orders that fall within the limits of Kyne. This result is especially surprising in that Congress has expressly approved only judicial review of unfair labor practice orders. See notes 24-32 infra and accompanying text. This note also does not discuss the relative merits of the courts of appeals and the district courts as forums for the initial review of Board representation orders.

17. See Cannery Warehousemen, Local 748 v. Haig Berberian, Inc., 623 F.2d 77 (9th Cir. 1980) (refusal by Board to defer to arbitrator's decision in determining coverage of collective bargaiming agreement); Termimal Freight Handling Co. v. Sotien, 444 F.2d 699 (8th Cir. 1971) (action to compel a regional director to seek an injunction against an alleged secondary boycott), cert. denied, 405 U.S. 996 (1972); Machinery Employees, Local 714 v. Madden, 343 F.2d 497 (7th Cir.) (action to enjoin an election to remove a union-shop authorization), cert. denied, 382 U.S. 822 (1965). See note 15 supra.

18. See, e.g., Rockford Redi-Mix Co. v. Zipp, 632 F.2d 30 (7th Cir. 1980), cert. denied, 101 S. Ct. 1388 (1981); Chicago Truck Drivers v. NLRB, 599 F.2d 816 (7th Cir. 1979); McCulloch v. Libbey-Oweus-Ford Glass Co., 403 F.2d 916 (D.C. Cir. 1968), cert. denied, 393 U.S. 1016 (1969); Greensboro Hosiery Mills, Inc. v. Johnston, 377 F.2d 28 (4th Cir. 1967); Local 1545, United Bhd. of Carpenters v. Vincent, 286 F.2d 127 (2d Cir. 1960); National Maritime Union v. NLRB, 375 F. Supp. 421 (E.D. Pa.), affd, 506 F.2d 1052 (3d Cir. 1974), cert. denied, 421 U.S. 963 (1975). 
the National Labor Relations Act provides the statutory procedures for selecting a bargaining representative. ${ }^{19}$ Under section 9(c)(1) either an einployer, a union, or an einployee can file a petition requesting that the Board hold a representation election. ${ }^{20}$ The Board will investigate this petition and hold a hearing if it has "reasonable cause to believe that a question of representation affecting coinunerce exists."21 If the evidence presented at the hearing deinonstrates sufficient need, the Board will conduct an election. Absent challenges to the propriety of the election, the Board will certify the union receiving a najority of the votes cast. ${ }^{22}$ Certification entitles a union to bargain with the einployer as the exclusive agent of its electorate. ${ }^{23}$

Provisions authorizing immediate judicial review of representation orders are conspicuously absent from section 9 of the Act. This omission resulted froin Congress's experience with the predecessor of section 9, Public Resolution 44.24 That statute permitted immediate judicial review of representation orders in the courts of appeals. ${ }^{25}$ By frequently appealing pre-election orders, some employers used this re-

19. 29 U.S.C. $\& 159$ (1976).

20. Id. \& 159 (c)(1) (1976). Section $9(c)(1)$ provides in full:

Whenever a petition shall have been filed, in accordance with such regulations as

nay be prescribed by the Board-

(A) by an einployee or group of einployees or any individual or labor organization acting in their behalf alleging that a substantial number of einployees (i) wish to be represented for collective bargaining and that their employer declines to recognize their representative as the representative defined in [section 9(a)], or (ii) assert that the individual or labor organization, which has been certified or is being currently recognized by their einployer as the bargaining representative, is no longer a representative as defined in [section 9(a)]; or

(B) by an employer, alleging that one or more individuals or labor organizations have presented to him a claim to be recognized as the representative defined in [section 9(a)];

the Board shall investigate such petition and if it has reasonable cause to beheve that a question of representation affecting coininerce exists shall provide for an appropriate hearing upon due notice. Such hearing may be conducted by an officer or employee of the regional office, who shall not make any recolninendations with respect thereto. If the Board finds upon the record of such bearing that such a question of representation exists, it shall direct an election by secret ballot and shall certify the results thereof.

An employer can also voluntarily recognize a union as the authorized bargaining representative for his employees. See R. Gorman, Labor Law 40 (1976). Section 9 is inapplicable to voluntary proceedings. See id.

21. 29 U.S.C. \& 159(c)(1) (1976).

22. Certification represents official Board approval of a union as the bargaining representative for a group of einployees. See generally Gorusan, supra note 20, at 40, 52-54. For a discussion of the importance of certification, see Cox, The Major Labor Decisions of the Supreme Court October Term 1958, 1959 Proceedings A.B.A. Section of LABOR ReL. L. 36, reprinted in $\mathrm{W}$. GELlHORN \& C. BYSE, ADMINISTRATIVE LAW 447 (6th ed. 1974).

23. For a detailed discassion of the election process, see C. Morrus, THE Developing LABOR LAW 153-266 (1971).

24. 48 Stat. 1183 (1934) (repealed 1935).

25. Id. $\S 2$. 
view procedure to postpone representation elections indefinitely. ${ }^{26} \mathrm{Be}-$ cause this practice was inimical to industrial peace, ${ }^{27}$ Congress purposefully omitted froin section 9 of the Act a provision allowing immediate access to the courts of appeals. ${ }^{28}$

Section $10(f)$ of the Act $^{29}$ appears to authorize immediate judicial review of representation orders in that it provides for immediate appellate review of all "final orders" issued by the Board. ${ }^{30}$ The Supreme Court has held, however, that representation orders are not final orders within the meaning of section $10(f){ }^{31}$ The Court acknowledged that a contrary holding would allow direct judicial imtervention into the representation process and opmed that this practice would subvert the carefully circumscribed review provisions of section 9.32

Although section 10(f) does not provide for immediate judicial review of Board representation orders, judicial review of these orders can be obtained indirectly under this section. ${ }^{33}$ To obtam judicial review a party inust first provoke an unfair labor practice ${ }^{34}$ charge after a representation election has occurred. The most common method of provoking such a charge is to refuse to bargain over the proposed collective agreement. ${ }^{35}$ After investigation of the charge, the Board issues either an order to remedy the unfair labor practice or an order dismissimg the charge. ${ }^{36}$ These orders are "final orders" within the meaning of section

26. See Goldberg, District Court Review of NLRB Representation Proceedings, 42 IND. L.J. 455,460 (1967).

27. The adverse effect on industrial peace resulting from the dilatory use of the courts was noted in the Senate Report on the Wagner Act:

Under Public Resolution 44, any attempt by the government to conduct an election of representatives may be contested $a b$ initio in the courts, although such election is in reality merely a preliminary determination of fact. This means that the government can be delayed indefinitely before it takes the first step toward industrial peace.

S. Rep. No. 573, 74th Cong., 1st Sess. 5-6 (1935).

28. See note 128 infra.

29. 29 U.S.C. $\$ 160(f)$ (1976). Section $10(f)$ provides:

Any person aggrieved by a final order of the Board granting or denying in whole or in part the relief sought may obtain a review of such order in any Umited States court of appeals in the circuit wherem the unfair labor practice in question was alleged to have been engaged im or wherein such person resides or transacts business, or im the United States Court of Appeals for the District of Columbia, by filing in such a court a written petition praying that the order of the Board be nodified or set aside.

30. Id.

31. See AFL v. NLRB, 308 U.S. 401, 412 (1940); NLRB v. IBEW, 308 U.S. 413, 414-15 (1940).

32. AFL v. NLRB, 308 U.S. 401, 408-12 (1940).

33. For further explanation of the section $10(f)$ method of review, see Goldberg, supra note 26 , at 491 .

34. An unfair labor practice is any action that violates section 8 of the Act. 29 U.S.C. $\S 158$ (1976).

35. See Goldberg, supra note 26 , at 491.

36. 29 U.S.C. $\$ 160(c)$ (1976). 
$10(\mathrm{f}) ;{ }^{37}$ any party aggrieved by a final order is entitled to immediate access to the courts of appeals. ${ }^{38}$ Because representation orders are reviewable incident to the review of an unfair labor practice order, ${ }^{39}$ the appellate court can review the propriety of the Board's representation orders when determining whether to enforce the Board's unfair labor practice order. 40

Generally, only einployers will provoke an unfair labor practice charge to gain judicial review because they have little to lose by delaying contract negotiations. A certified union usually will not delay the bargaining process, for it has a vested interest in obtaining a collective bargaining agreeinent. Moreover, if a certified union refuses to bargain, the employer might not file an unfair labor practice charge. The union's refusal to bargain in this situation not only reduces the employees' confidence in the union's ability to negotiate a contract, but also fails to produce judicial review of the Board's representation order. Thus, section 10(f) does little to provide a certified union with a method by which it can obtain judicial review of Board representation orders. ${ }^{41}$

Section 8(b)(7)(B) of the Act theoretically provides an indirect method of appellate review for a union that has recently lost a representation election. ${ }^{42}$ This section declares that recognitional picketing,

37. See AFL v. NLRB, 308 U.S. 401,409 (1940).

38. See note 29 supra.

39. The specific language authorizing this practice is found in section $9(d)$ of the Act, 29 U.S.C. $§ 159(d)$ (1976):

Whenever an [unfair labor practice] order of the Board . . . is based in whole or in part upon facts certified following an investigation pursuant to [section 9(c)] . . . and there is a petition for the enforcement or review of such order, such certification and the record of such investigation shall be included in the transcript of the entire record required to be filed under section $10(\mathrm{e})$ or $10(\mathrm{f})$, and thereupon the decree of the court enforcing, modifying, or setting aside in whole or in part the order of the Board shall be made and entered upon the pleadings, testimony, and proceedings set forth in such transcript.

See Pittsburgh Plate Glass Co. v. NLRB, 313 U.S. 146, 154 (1941); Goldberg, supra note 26, at 456-57.

40. The reason for the rather circuitous method of review provided by section $10(f)$ is explained by Gorman:

The object of this [method of review] is to deter dilatory challenges in the midst of representation cases which will delay the conduct of an election and the prompt recording of employee preferences on collective bargaining; inoreover, the outcome of the election will in many instances render inoot the challenges to the Board representation findings.

GORMAN, supra note 20, at 11 .

41. For an example of when a certified union would seek judicial review under section $10(f)$, see Leedom v. Kyne, 358 U.S. 184, 186 (1958). Section 10(f) also may not provide interested third parties with means to secure judicial review of Board representation orders. See Florida Bd. of Business Regulation v. NLRB, 497 F. Supp. 599, 602 (M.D. Fla. 1980) (State of Florida, seeking review of Board orders asserting jurisdiction over jai-alai industry, would not be able to secure review under section $10(f)$ if jai-alai employer did not institute an unfair labor practice proceeding).

42. 29 U.S.C. $\S 158(b)(7)(B)(1976)$. 
or the threat of such picketing, is an unfair labor practice when a valid election has been conducted during the preceding twelve months. ${ }^{43}$ To invoke this method of review, the union pickets the target employer for recognition after losing the representation election. ${ }^{44}$ If the employer files a section $8(\mathrm{~b})(7)(B)$ unfair labor practice charge against the union, the Board investigates the charge and, if it deems appropriate, uses its injunctive power under section 10(a) of the $\mathrm{Act}^{45}$ to restrain the picketing. The issuance of an injunction results in "a reviewable 'final order by the Board . . ." "which can be appealed immediately. ${ }^{46}$ The propriety of the certification proceeding is reviewed incident to this appeal. ${ }^{47}$ Courts have disagreed over whether section $8(\mathrm{~b})(7)(B)$ presents a practical method of post-election review. 48 Judge Lunibard of the Court of Appeals for the Second Circuit found "no reason . . . why this approach would not provide an adequate vehicle for eventual review of the Board's determination." 49 The Court of Appeals for the Third Circuit, in $N L R B$ v. Interstate Dress Carriers, Inc., ${ }^{\text {,0 }}$ identified three reasons that support a contrary conclusion. First, an employee can be discharged for cause if he pickets in violation of section $8(\mathrm{~b})(7)(B){ }^{51}$ The employee therefore has little incentive to initiate the section $8(b)(7)(B)$ review process. Further, a union that has recently lost a representation election probably does not have the influence nec-

43. Id. Section 8(b)(7)(B) provides:

It shall be an unfair labor practice for a labor organization or its agents-

(7) to picket or cause to be picketed, or threaten to picket or cause to be picketed, any employer where an object thereof is forcing or requiring an employer to recognize or bargain with a labor organization as the representative of his employees, or forcing or requiring the employees of an employer to accept or select such labor organization as their collective bargaining representative, unless such labor organization is currently certified as the representative of such employees:

(B) where within the preceding twelve months a valid election under section $9(\mathrm{c})$ of this Act has been conducted....

44. For a more eomplete discussion of the procedures necessary to imvoke section $8(\mathrm{~b})(7)(\mathrm{B})$, see Goldberg, supra note 26, at 503-04.

45. 29 U.S.C. \& 160(a) (1976). Section 10(a) empowers the Board "to prevent any person from eugaging in any unfair labor practice . . . affecting commerce."

46. Umited Fed'n of College Teachers, Local 1460 v. Miller, 479 F.2d 1074, 1079 (2d Cir. 1973) (quoting Herald Co. v. Vimcent, 392 F.2d 354, 356 (2d Cir. 1968)).

47. Sce uote 39 supra and accompanying text.

48. Compare Cannery Warehousemen, Local 748 v. Haig Berberian, Inc., 623 F.2d 77, 80-81 n.4 (9th Cir. 1980) and United Fed'n of College Teachers, Local 1460 v. Miller, 479 F.2d 1074, 1079 (2d Cir. 1973) (holding section 8(b)(7)(B) to be a feasible method of post-election review) with NLRB v. Interstate Dress Carriers, Inc., 610 F.2d 99, 108-09 (3d Cir. 1979) (concluding that the remedy under section $8(b)(7)(B)$ is too speculative to be considered realistically available). 1973).

49. United Fed'n of College Teachers, Local 1460 v. Miller, 479 F.2d 1074, 1079 (2d Cir.

50. 610 F.2d 99 (3d Cir. 1979).

51. Id. at 109. 
essary to convince employees to disregard the risk of discharge. Second, it is the employer who must file the unfair labor practice charge which enables the union to obtaim access to the appellate courts. ${ }^{52}$ Generally, an employer will file the unfair labor practice charge only if he finds the picketing disruptive. ${ }^{53}$ A union's ability to secure judicial review of Board representation orders under section $8(\mathrm{~b})(7)(B)$ is thus uncertain because it depends on the employer's assessment of the need to enjoim the picketing. Third, courts probably will not countenance disruptive picketing under section $8(\mathrm{~b})(7)(B)$ because such picketing contravenes that section's purpose: to limit disturbances of imdustrial peace..$^{54}$

The concerns enumerated in Interstate Dress Carriers indicate that section 8(b)(7)(B) is an impractical method of obtaining appellate review of representation orders. Under section $10(f)$ of the Act only einployers are assured judicial review of Board representation orders. The Act therefore allows judicial review of Board representation orders only im limited circunistances: when an employer seeks such review in the courts of appeals after the representation election has occurred.

\section{B. The Fay, Kyne, and Sociedad Nacional Exceptions to Direct Judicial Intervention in the Representation Process.}

Although the Act prohibits immediate appellate review of representation orders and limits post-election appellate review of these orders, it does not state whether district courts have jurisdiction to immediately review representation orders. This issue was addressed in a trio of cases, beginning with Fay v. Douds. ${ }^{5 s}$ In Fay Judge Learned Hand proposed, im dicta, that district courts have jurisdiction to imtervene in the representation process if a party's claim, im atteinpting to establish that the Board deprived that party of a constitutional right, is

\section{Id at 108-09.}

53. Id.

54. Id at 109.

55. 172 F.2d 720 (2d Cir. 1949). Fay involved a representation dispute between two unions. Local 475, United Electrical Workers was the incumbent union. It was reuegotiating its collective bargaining agreeınent when the United Automobile Workers filed a petition for certification as the exclusive bargaining representative of the employees that Local 475 represented. Because Local 475 had not complied with sections $9(\mathrm{f}), 9(\mathrm{~g})$, and $9(\mathrm{~h})$ of the Act, 29 U.S.C. $\S 159(\mathrm{f})$-(h) (1976), it lacked status to object to the holding of a consent election. The Board therefore duly ordered an election without holding any preliminary hearings. Local 475 lost the election and sought rehef in the district court, alleging the unconstitutional deprivation of its procedural due process rights as a result of the Board's failure to conduct a formal hearing before the holding of the election. 172 F.2d at 723 . 
not "transparently frivolous." 56 Judge Hand intended the transparently frivolous limitation to allow district courts to deny jurisdiction when a party merely disagreed with the inanner in which the Board conducted the representation proceeding. Notwithstanding this qualification, Fay possesses potentially enormous breadth. Because any arguable deprivation of due process rights meets its standard, Fay could authorize unlimited district court jurisdiction. ${ }^{57}$ This problem has led several courts to question Fay. ${ }^{58}$ Other courts have modified the Fay standard in an attempt to narrow its potential breadth. ${ }^{59}$ No modification has been generally accepted by the courts, however, and it is highly doubtful that Fay is still authoritative law. ${ }^{60}$

A second ground for district court jurisdiction is found in $\mathrm{McCul}$ loch v. Sociedad Nacional de Marineros de Honduras. ${ }^{61}$ In McCulloch several seagoing vessels were beneficially owned by an American corporation, but were legally owned by the corporation's foreign subsidiary. ${ }^{62}$ The ships flew the flags of foreign nations and employed foreign crews; foreign unions represented the crews. The Board nevertheless

56. $172 \mathrm{~F} .2 \mathrm{~d}$ at 723 . Judge Hand also stated in dicta that "having once acquired jurisdiction, the [district] court might, and should, dispose of all other questions which arose, even though they would not have been independently justiciable." Id. This reasoning has not been adopted by any court. For an enlightening analysis of this dicta, see Goldberg, supra note 26, at 466-69.

57. See Blue Cross \& Blue Shield v. NLRB, 609 F.2d 240, 244 (6th Cir. 1979).

58. See, e.g., Amalgamated Meat Cutters, Local 576 v. Allen, 423 F.2d 267, 269 (8th Cir. 1970); Herald Co. v. Vincent, 392 F.2d 354, 359 (2d Cir. 1968); Greensboro Hosiery Mills, Inc. v. Johnston, 377 F.2d 28, 32 (4th Cir. 1967); Boire v. Miami Herald Pubhshing Co., 343 F.2d 17, 21 n.7 (5th Cir.), cert. denied, 382 U.S. 824 (1965). But see Florida Bd. of Business Regulation v. NLRB, 497 F. Supp. 599, 602 (M.D. Fla. 1980) (using Fay as an alternative ground for jurisdiction). The Supreine Court has never adopted the Fay standard.

59. A recurring, but not generally accepted, modification of Fay provides that the denial of a substantial constitutional right is sufficient for district court jurisdiction. See Squillacote v. lnternational Bhd. of Teamsters, Local 344, 561 F.2d 31, 37-39 (7th Cir. 1977) (because the "transparently frivolous" standard can be so easily satisfied, jurisdiction should only be granted when a plain violation of a constitutional right is alleged); United Fed'n of College Teachers, Local 1460 v. Miller, 479 F.2d 1074, 1080 (2d Cir. 1973) (dissent) (violation of due process clause of fifth amendment allows district court to grant jurisdiction under the Fay doctrine); McCormick v. Hirsch, 460 F. Supp. 1337, 1347 (M.D. Pa. 1978) ("[W]hile nere allegations of constitutional deprivations may not be sufficient to vest jurisdiction in the District Court, a clearly colorable claim ... is sufficient to require the District Court to intervene to protect constitutional rights") (footnote omitted). But cf. Firestone Tire \& Rubber Co. v. Samoff, 365 F.2d 625, 628 (3d Cir. 1966) ("The question whether the Constitution [requires a pre-election hearing] is not of itself grounds for jurisdiction in the district court").

60. A reformulation of Fay is not attempted in this note. A proper analysis of Fay would require the determination of whether Congress can deny access to the federal court system even though a party's due process rights have been violated by a regulatory agency. This question arises if Fay is rejected as authoritative precedent, see note 58 supra, and the Board violates the due process rights of an unsuccessful union.

61. 372 U.S. 10 (1963).

62. Id at 13. 
decided that the Act covered the foreign seamen and ordered a representation election ${ }^{63}$ to determine their proper bargaining representative. The Board's assertion of jurisdiction aroused vigorous protests from foreign governments. The United States District Court for the District of Columbia exercised jurisdiction over the dispute and enjomed the Board from conductimg the elections. ${ }^{64}$ The Supreme Court affirmed the district court's decision and mdicated that jurisdiction is properly exercised in "the presence of public questions particularly high in the scale of our national interest because of their international complexion." 65

In Leedom v. Kyne $e^{66}$ the Supreme Court developed a third ground for district court jurisdiction to review Board representation orders. In Kyne a labor organization petitioned the Board for certification as the exclusive collective bargaining agent for the nonsupervisory professional employees of a Westinghouse Corporation plant. The Board held a hearmg on the petition. It concluded that the appropriate bargaining unit should include the 233 professional employees the union desired to represent as well as nine nonprofessional einployees. The Board included the latter imdividuals in the bargaining unit because they shared a "close community of employment imterests" with the professional employees. ${ }^{67}$ The union requested that the Board conduct an election among the professional employees to determine if they favored inclusion in a mixed bargaining unit. The Board refused to do so despite section 9(b)(1) of the Act, ${ }^{68}$ which provides that "the Board shall not . . . decide that any unit is appropriate" if it mcludes both professional and nonprofessional employees unless "a majority of . . . [the] professional employees vote [to be included] in such a unit." 69 The union was certified as the exclusive bargaining agent for the mixed unit, but it brought an action in the district court to set aside the certification order because of the inclusion of the nonprofessional employees. ${ }^{70}$

63. Id. at 13-14.

64. Empresa Hondurena De Vapores, S.A. v. McLeod, 200 F. Supp. 484 (S.D.N.Y. 1961), rev'd 300 F.2d 222 (2d Cir. 1962), affd sub nom., McCulloch v. Sociedad Nacional de Marineros de Honduras, 372 U.S. 10 (1963).

65. 372 U.S. at 17. Sociedad Nacional also has significance in determining what activities are snfficiently "in commerce" to be within the Board's jurisdiction. Id. at 17-22. For other cases that delineate the scope of the words "in commerce," see Incres Steamship Co. v. International Maritime Workers Union, 372 U.S. 24 (1963); Benz v. Compania Naviera Hidalgo, 353 U.S. 138 (1957).

66. 358 U.S. 184 (1958)

67. Id. at 186.

68. 29 U.S.C. § $159(\mathrm{~b})(1)(1976)$.

69. Id.

70. The Board later admitted that its refusal to conduct a vote among the professional em- 
The United States District Court for the District of Colunibia held that it had jurisdiction to grant the requested relief because the Board lacked autliority to disregard the "mandatory limitation" of section 9(b)(1). ${ }^{71}$ The district court also concluded that the Board's refusal to conduct the required election caused irreparable damage to the right afforded professional employees by section 9(b)(1). ${ }^{72}$ The Court of Appeals for the District of Columbia Circuit affirmed. ${ }^{73}$ The court of appeals held that the Board's action violated a statutory provision "intended to protect . . . professionals; that the professionals' riglit" to the benefit provided by the statute did "not depend on Board discretion or expertise; and that denial of [the right resulted] in injury."74

The Supreme Court affirmed the decision of the court of appeals. 75 The majority based its conclusion on the unauthorized nature of the Board's action:

This suit . . . is one to strike down an order of the Board made in excess of its delegated powers and contrary to a specific prohibition in the act. Section $9(b)(1)$ is clear and mandatory. . . . [T] The Board ... attempted [an] exercise of power that had been specifically withheld. It deprived the professional employees of a "right" assured to them by Congress. Surely, in these circumstances, a Federal District Court has jurisdiction of an original suit to prevent deprivation of a right so given. ${ }^{76}$

The majority rejected the Board's argument that jurisdiction should be denied because Congress created no express reinedy to redress violations of section 9 (b)(1). The Court observed tliat section 9(b)(1) was stated in prohibitory terms and held that Congress intended that statutory prohibitions, whicl are definite in meaning, be judicially enforced. The court contrasted statutory language cast in prohibitory terms and statutory language expressed as a inandate:

While an affirmative declaration of duty contained in a legislative enactment may be of imperfect obligation because not enforceable in terms, a definite statutory prohibition of conduct which would thwart

ployees did violate a specific prohibition in the Act. 358 U.S. at 187. Limiting the Kyne holding to its facts, however, would permit the Board to evade judicial review simply by not admitting to its wrongdoing. See National Maritime Union v. NLRB, 375 F. Supp. 421,430 (E.D. Pa.), affd, 506 F.2d 1052 (3d Cir. 1974), cert. denied, 421 U.S. 963 (1975).

71. Kyne v. Leedon, 148 F. Supp. 597, 601 (D.D.C. 1956), affd, 249 F.2d 490 (D.C. Cir. 1957), affd, 358 U.S. 184 (1958).

72. 148 F. Supp. at 601 .

73. Leedoin v. Kyne, 249 F.2d 490 (D.C. Cir. 1957), affd, 358 U.S. 184 (1958).

74. 249 F.2d at 491.

75. Leedonı v. Kyne, 358 U.S. 184 (1958).

76. Id. at 188-89. 
the declared purpose of the legislation cannot be disregarded. . . . The definite prohibition which Congress inserted in the Act can not therefore be overriden in the view that Congress intended it to be ignored. ${ }^{77}$

Finally, the Court distinguished Switchmen's Union v. National Mediation Board. ${ }^{78}$ In Switchmen's Union the Court held that a district court did not have jurisdiction to review a representation order issued by the National Mediation Board (NMB) because the NMB had acted within its statutory powers. ${ }^{79}$ The Kyne Court stated that in Switchmen's Union no congressionally created right could have been violated by the denial of district court jurisdiction because the NMB had not violated any statutory constraint. In Kyne, however, the Court reasoned that foreclosing jurisdiction would have allowed the Board to deny professional einployees their section $9(\mathrm{~b})(1)$ rights. The Court reached this conclusion because the professional einployees in Kyne had "no other ineans within their control . . . to protect and enforce" these rights. ${ }^{80}$

The Kyne opinion left three questions unanswered. First, the Kyne inajority did not indicate whether district courts may exercise jurisdiction in cases involving alleged Board violations of provisions of the Act cast in inandatory language. Second, the significance of the following concern is unclear: the denial of district court jurisdiction can insulate Board representation orders from judicial review. Third, the Kyne Court never addressed the issue of whether district court ju-

77. Id at 189 .

78. 320 U.S. 297 (1942).

79. Id. at 300 .

80. 358 U.S. at 190. Justice Brennan, joined by Justice Frankfurter, dissented in Kyne. Justice Brennan concluded that nothing in the Act or its legislative history indicated that Congress intended the representation process to be interrupted by judicial review of Board orders, even when the order was based on an alleged misinterpretation of the Act. Id. at 191-95. He asserted that the majority's decision opened "a gaping hole in [the] congressional wall against direct resort to the courts" because any party alleging unlawful Board action could bring a case immediately in a district court. Id. at 914 .

Justice Brennan also contended that the Court's reliance on Switchmen's Union was misplaced. He argued that Switchmen's Union held merely that access to the district courts should be allowed when Congress creates a right without creating a tribunal for its enforcement. Congress created the Board specifically to protect the rights embodied in the Act. Thus there was no reason to allow jurisdiction in Kyne. Id at 197-201. Justice Brennan stated that any inequity in the procedure resulted from the congressional decision that the need to prevent the disruption of the representation process outweighed the hardship that might result from the absence of judicial review. Id at 197.

For further analysis of the Kyne opinion, see Goldberg, supra note 26, at 470-90; Comment, Judicial Review of Preliminary Orders of National Administrative Agencies After Leedom v. Kyne, 8 Buffalo L. Rev. 372 (1959); 73 HaRv. L. Rev. 217 (1959); 57 Mich. L. Rev. 910 (1959). 
risdiction should be denied to a party who could secure judicial review of Board representation orders after the representation election.

\section{EXTENSIONS OF LEEDOM v. KYNE}

\section{A. Early Extensions.}

The first decision ${ }^{81}$ to apply the Kyne standard to alleged Board violations of statutory nuandates was Miami Newspaper Printing Pressman's Local 46 v. McCulloch. ${ }^{82}$ In Miami Newspaper the Board conducted a representation election and then set it aside because of an infirmity in its own procedure. After conducting a subsequent hearing, the Board affirmed the validity of the original election. Rather than reinstating the initial results, however, the Board ordered the regional

81. Before the Kyne test was applied to statutory mandates, the Court modified the standard in Boire v. Greyhound Corp., 376 U.S. 473 (1964). In Boire the Board determined that Greyhound Corporation and Floors Corporation were joint enployers of a group of bus-terminal maintenance employees and that the unit consisting of all employees under the joimt-employer relationship was the appropriate unit for a representation election. Id. at 475 . Greylound disagreed and filed suit in district court to set aside the Board's decision and enjom the election. The district court exercised jurisdiction on the basis of Kyme and granted the injunction, concluding that the Board's findings were legally insufficient to establish a joint-employer relationship. Greyhound Corp. v. Boire, 205 F. Supp. 686 (S.D. Fla.), affd, 309 F.2d 397 (5th Cir. 1962), rev'd, 376 U.S. 473 (1964). The court of appeals affirmed. Boire v. Greylound Corp., 309 F.2d 397 (5th Cir. 1962), rev'd, 376 U.S. 473 (1964). The Supreme Court reversed the decisions of the lower courts, categorizing the joint-employer issue as "essentially . . . factual" and holding that Kyne is limited to questions that depend solely on the construction of the Act. 376 U.S. at 481-82.

Boire substantially limits the ainbit of $K y n e$ and usefully allocates matters between the Board and the courts when the distinction between law and fact is clear. Often, however, the issue presented involves inseparable questions of statutory interpretation and fact. For exainple, in McCormick v. Hirsch, 460 F. Supp. 1337 (M.D. Pa. 1978), a union filed a representation petition with the Board. It sought certification as the exclusive bargaining representative of teachers employed at a parochial high school. The Board began an investigation to determine if a representation learing was necessary. Upon the scheduling of a hearing by the Board, the superintendent of the school system filed suit in the district court. He requested a temporary restraining order and an imjunction, contending that the Act, as applied, violated his religious liberties guaranteed by the first anendment. Id. at 1340 .

In determining whether to exercise jurisdiction, the court in McCormick faced inseparable questions of fact and statutory interpretation: the court had to decide whether a parochial sclool was an employer within the meaning of section 2(2) of the Act, 29 U.S.C. \& 152(2) (1976), and whether Congress intended the Act to extend to rehious institutions. After examining the language of the Act and its legislative history, the court granted jurisdiction on the basis of Kyne. The court held that the Board "would be acting beyond the grant of power given by Congress in the Act" if it were allowed to conduct representation proceedings involving parochial schools. 460 F. Supp. at 1345.

The court in McCormick did not rely on Boire in reaching its decision. Because of the mextricable nature of the questions of law and fact presented, Boire could not have aided the court in its jurisdictional determinations. But see Grutka v. Barbour, 549 F.2d 5, 8 (7th Cir.), cert. denied, 431 U.S. 908 (1977) (court rejected argunients that the "matter of law/matter of fact distinction . . . is an overly facile solution to the problem of when district court jurisdiction is appropriate").

82. 322 F.2d 993 (D.C. Cir. 1963). 
director to conduct a second election, whereupon a union filed suit in the district court to compel the Board to certify the results of the first election. The union contended that because the origimal election was found to have been properly conducted, the Board was required to affirm its validity pursuant to section $9(\mathrm{c})(1)^{83}$ of the Act. The relevant portion of that section provides: "If the Board finds . . . that . . . a question of representation exists, it shall direct an election by secret ballot and shall certify the results thereof." 84 In holding that the Kyne standard applied to the statutory mandate found in section 9(c)(1), the court reasoned that a "party would be as aggrieved by [a failure of the Board to act pursuant to a statutory mandate] as by an act of the Board contrary to an express prohibition [of the Act]." 85

The Miami Newspaper decision is important because many of the provisions of the Act that regulate the representation process are cast in mandatory language. ${ }^{86}$ Miami Newspaper complicates the judicial inquiry required under Kyne because more extensive analysis is often necessary to determine whether a statutory inandate, as opposed to a statutory prohibition, confers district court jurisdiction. Statutory prohibitions are absolute; a court can determine if the Board has violated a prohibitory provision of the Act merely by examining the face of the Act. ${ }^{87}$ In contrast, courts frequently nust look beyond the face of the Act to ascertain whether a statutory mandate confers district court jurisdiction, for Congress and the courts have allowed the Board to exercise discretion under these provisions. ${ }^{88}$

An example of a statutory mandate that provides for Board discretion is section 9(c)(1) of the Act. ${ }^{89}$ It states that if "the Board finds . . . that . . . a question of representation exists, it shall direct an election . . . and shall certify the results thereof."90 The Board may exercise its

83. 29 U.S.C. $\$ 159$ (c)(1) (1976). For the text of this section, see note 20 supra.

84. Id. (emphasis added).

85. 322 F.2d at 977. Since Miami Newspaper, courts frequently have applied Kyne to mandatory provisions of the Act. See, eg., Newport News Shipbuilding \& Dry Dock Co. v. NLRB, 633 F.2d 1079 (4th Cir. 1980) (section 9(c)(1), 29 U.S.C. § 159(c)(1) (1976)); Surrat v. NLRB, 463 F.2d 378 (5th Cir. 1972) (section 9(c)(1)); Templeton v. Dixie Color Printing Co., 444 F.2d 1064, 1069 (5th Cir. 1971) (section 9(c)(1)); Bullard Co. v. NLRB, 253 F. Supp. 391 (D.D.C. 1966) (section 9(e), 29 U.S.C. \& 159(e) (1976)).

86. See 29 U.S.C. \& 159 (1976). See generally Cox, The Major Labor Decisions of the Supreme Court October Term 1958, 1959 Proceedings OF A.B.A. SECTION OF LABOR REL. L. 23, reprinted in W. GeLlhoRn \& C. BYSE, ADMINISTRATIVE LAW 441 (6th ed. 1974). See note 20 supra.

87. See Leedom v. Kyne, 358 U.S. 184, 189 (1958) (quoting Texas \& N.O.R. v. Brotherlood of Ry. \& S.S. Clerks, 281 U.S. 548, 568-69 (1930)). See text accompanying note 77 supra.

88. See note 9 supra.

89. 29 U.S.C. $\$ 159$ (c)(1) (1976). See note 20 supra.

90. 29 U.S.C. § 159(c)(1) (1976) (emphasis added). 
discretion under section 9(c)(1) to prevent the holding of a representation election by applying the contract-bar doctrine.91 The Board can also decline to exercise jurisdiction under section 9(c)(1) when statutory jurisdiction exists if it determines that the assertion of jurisdiction would not further the purposes of the Act.92 To avoid infringeinent on the Board's discretion, ${ }^{93}$ therefore, a jurisdictional standard inust adequately focus the court's attention on whether a statutory mandate commands immediate Board action.

The Kyne standard, which prohibits Board action taken "in excess of its delegated powers and contrary to a statutory prohibition,"94 provides little guidance for determining jurisdiction in cases involving alleged violations of statutory mandates. ${ }^{95}$ This inadequacy of the Kyne test is illustrated by Templeton v. Dixie Color Printing Co. ${ }^{96}$ In Templeton the Board used one of its discretionary tools, the blocking-charge doctrine, ${ }^{97}$ to hold an employee decertification petition in abeyance for over three years.98 Four einployees filed suit to coinpel the Board to investigate the petition. The Court of Appeals for the Fifth Circuit, in affirming the district court's exercise of jurisdiction under Kyne, held that the Board's refusal to take notice of the petition was arbitrary and

91. The contract-bar doctrine is a discretionary tool that permits the Board to dismiss an election petition filed within either the first three years or the duration of a collective bargaining agreement, whichever is less. See GoRMAN, supra note 20, at 54-59.

92. See NLRB v. Denver Bldg. \& Constr. Trades Council, 341 U.S. 675, 684 (1951); National Maritime Union v. NLRB, 375 F. Supp. 421, 433 (E.D. Pa.), affd, 506 F.2d 1052 (3d Cir. 1974), cert. denied, 421 U.S. 963 (1975); Council 19, Am. Fed'n of State Employees v. NLRB, 296 F. Supp. 1100, 1104 (N.D. IIl. 1968).

93. See notes 11-12 supra and accompanying text.

94. Leedom v. Kyne, 358 U.S. 184, 188 (1958). See text accompanying note 76 supra.

95. The mability of the Kyne standard to provide useful jurisdictional guidelines has led several courts to reformulate the standard. See Squillacote v. International Bhd. of Teamsters, Local 344, 561 F.2d 31, 39 (7th Cir. 1977) (Kyne apphies ouly to a plain violation of a statutory or constitutional right); Uyeda v. Brooks, 365 F.2d 326, 331 (6th Cir. 1966) (procedural provisions of the Act cannot be read as prohibitious limiting the Board's power under $K y n e$ ); Newport News Shipbuilding \& Drydock Co. v. NLRB, 498 F. Supp. 267, 271 (E.D. Va. 1980) (Kyne authorizes an "arbitrary and capricious" standard of review); National Maritime Umion v. NLRB, 375 F. Supp. 421, 429-30 (E.D. Pa.) (district courts should apply an ad hoc test to determine if the provision under scrutiny is sufficiently "clear and mandatory" to confer jurisdiction), affd, 506 F.2d 1052 (3d Cir. 1974), cert. denied, 421 U.S. 963 (1975); accord, United States v. Feaster, 410 F.2d 1354, 1368 (5th Cir.) (Kyne permits access to the district courts under the Railway Labor Act, 45 U.S.C. $\$ \S 151-188$ (1976), "ouly if the Mediation Board's determination is infused with error which is of a summa or magna quality as contraposed to decisions which are simply cum error"), cert. denied, 396 U.S. 962 (1969).

96. 444 F.2d 1064 (5th Cir. 197I).

97. The blocking-charge doctrine allows the Board to refuse to conduct a representation election if unfair labor practice charges are pending before it. See id. at 1065 .

98. The Board delayed investigation of the decertification petition for over three years because both the employer and the incunbent union had filed numerous unfair labor practice charges. Id. at 1066 . 
contrary to the specific mandate of section 9(c)(1).99 Emphasizing that no adequate administrative relief was available to the plaintiffs, ${ }^{100}$ the court ordered the Board to investigate the decertification petition.

Because the jurisdictional standard used in Templeton did not adequately account for Board discretion, the court failed to consider fully the nature of the Board action. Had the standard focused the court's attention on this consideration, the unwarranted judicial interference that occurred in Templeton might have been avoided. This infringement on the Board's discretion frustrated an underlying policy of the Act: to rely on the Board's administrative expertise to resolve labor disputes. ${ }^{101}$

The Templeton decision also illustrates a second shortcoming of the Kyne standard: Kyne's failure to indicatc the significance to be attached to a party's ability to secure judicial or adininistrative review of a Board order if district court jurisdiction is denied. In Templeton the court took notice of the unavailability of an effective administrative remedy. ${ }^{102}$ Other courts have suggested that district court jurisdiction should be predicated on the absence of alternative forins of judicial or administrative rehef. ${ }^{103}$

Resolution of this question is inportant. For some parties, such as unsuccessful unions, the district courts represent the only avenue of access to the judiciary. ${ }^{104}$ The dissent in Physicians National House Staff Association v. Fanning 105 recognized the importance of considering the disparity between parties' abilities to secure judicial review of Board representation orders. The dissent therefore reformulated the Kyne standard in an attempt to render it more useful.

B. The Physicians Standard.

In Physicians National House Staff Association v. Fanning ${ }^{106}$ an

99. Id. at 1068-70. For the text of section $9(\mathrm{c})(1)$, see note 20 supra.

100. 444 F.2d at 1069.

101. See Meltzer, The Supreme Court, Congress, and State Jurisdiction over Labor Relations: II, 59 CoLuM. L. Rev. 269, 299 (1959). Meltzer explains how repeated district court intervention would result in the subjugation of the Board's delegated powers to conduct representation elections:

[1]ndirect judicial control over the Board's [representation] machinery . . . would either bring the Board and the courts into direct conflict in which courts, by virtue of their broad equity powers, would prevail, or it would subordinate Board action to judicial determinations in an area which deinands all of the special insights and expertise inputed to the Board.

102. $444 \mathrm{~F} .2 \mathrm{~d}$ at 1069.

103. See note 147 infra.

104. See notes $42-54$ supra and accompanying text.

105. 642 F.2d 492 (D.C. Cir. 1980) (en banc), cert. denied, 101 S. Ct. 1360 (1981).

106. Id. 
employee association sought to organize the house staff of several hospitals. House staff are physicians who serve as interns, residents, and clinical fellows. The Board had determined that house staff were not employees within the meaning of section 2(3) of the Act. ${ }^{107}$ The Board therefore refused to conduct representation elections at the various hospitals. The employee association sought rehef in the district court, contending that both section 2(3) of the Act and the legislative history accompanying the 1974 amendments to the Act ${ }^{108}$ provide a clear mandate to the Board to classify house staff as einployees. ${ }^{109}$

The Court of Appeals for the District of Columbia Circuit, sitting en banc, refused to grant jurisdiction under Kyne. ${ }^{110}$ The majority found no statutory mandate on the face of section 2(3). Rather, the court considered the determination of whether house staff are einployees to be essentially a factual question and therefore beyond the jurisdiction of the district court:

The appellants attempt to find in section 2(3) of the Act . . the clear statutory mandate required by Leedom v. Kyne. We think the attempt fails. That section does not define the term employee nor does any other section of the Act. Whether a particular individual is an employee depends upon the facts. The task of decision on the facts of each case is assigned to the National Labor Relations Board and in making that decision the Board exercises its informed discretion. ${ }^{111}$

107. See Cedars-Sinai Medical Center, 223 N.L.R.B. 251 (1976). Section 2(3), 29 U.S.C. $\S 152(3)$ (1976), provides in part:

The term "einployce" shall include any einployee, and shall not be limited to the einployees of a particular employer... and shall include any individual whose work has ceased as a consequence of, or in connection with, any current labor dispute or because of any unfair labor practice, and who has not obtained any other regular and substantially equivalent einployinent. . . .

108. The 1974 amendments to the Act removed the exemption for non-profit hospitals from the definition of employer. See Pub. L. No. 93-360, 88 Stat. 395 (1974).

109. 642 F.2d at 494.

110. Id. at 500. The district court had held that it lacked jurisdiction to review the Board's order because the question of whether the house staff were einployees was "primarily a factual and definitional determination of the type traditionally left to the discretion of the Board." Physicians Nat'l House Staff Ass'n v. Murphy, 443 F. Supp. 806, 810 (D.D.C. 1978), affd sub nom, Physicians Nat'1 House Staff Ass'n v. Fanning, 642 F.2d 492 (D.C. Cir. 1980) (en banc), cert. denied, 101 S. Ct. 1360 (1981). On appeal, Chief Judge Wright proposed a reformulation of the Kyne standard and concluded that under the reformulation the district court should have exercised jurisdiction. Physicians Nat'l House Staff Ass'n v. Murphy, 100 L.R.R.M. 3055 (D.C. Cir. Apr. 2), vacated pending rehearing en banc, 104 L.R.R.M. 2592 (D.C. Cir. Junc 5, 1979). In reaching this conclusion he einphasized the affirmative congressional intent to classify house staff as einployees within the ineaning of section 2(3) of the Act, 29 U.S.C. $\$ 152(3)$ (1976), and the absence of any feasible recourse to the judiciary other than through the exercise of district court jurisdiction. See 100 L.R.R.M. at 3060, 3062. In the en banc decision, Chief Judge Wright lost his majority and restated his proposed standard in his dissent. Physicians Nat'l House Staff Ass'n v. Fanning, 642 F.2d 492 (D.C. Cir. 1980) (en banc), cert. denied, 101 S. Ct. 1360 (1981). See notes 114-117 infra and accompanying text.

111. 642 F.2d at 496 (footnote omitted). 
The court rejected the contention that the legislative history of the Act provides the statutory mandate necessary to grant jurisdiction under Kyne. It found no evidence that Congress intended house staff to be classified as einployees. ${ }^{12}$ Finally, the court was unpersuaded by the argument that if jurisdiction were denied, the Board's order excluding house staff from the coverage of the Act would never be subject to judicial review. The majority emphasized that Congress had considered this hardship but had determined that the need for timely representation elections overrode this concern. ${ }^{13}$

Chief Judge Wright, in his dissent, concluded that no meaningful jurisdictional determination could be made without a more precise standard. He identified four considerations relevant to the determination of jurisdiction under Kyne:

(A) whether the alleged error by the Board involved a question of statutory interpretation or inerely an issue of fact; (B) whether the statutory provision is "clear and mandatory" in creating rights for those subject to the NLRA; (C) whether the party challenging the Board's action has a realistic hope of eventual court review following an unfair labor practice order; and (D) the potential for thwarting the purposes of the NLRA which would flow from finding jurisdiction in [each] case. ${ }^{114}$

Chief Judge Wright concluded that jurisdiction existed in Physicians in light of these considerations. Contrary to the majority, he found a clear congressional intent in the legislative history of the Act to categorize house staff as employees. ${ }^{115}$ He also noted the association's inability to secure subsequent judicial review if jurisdiction were denied. ${ }^{116} \mathrm{He}$ concluded by arguing that because the house staff were excluded from the coverage of the Act, a grant of district court jurisdiction could not possibly delay the collective bargaining process, for no representation election was being conducted. ${ }^{117}$

The dissent's test recognizes the need to formulate an effective jurisdictional standard. Such a standard must provide guidelines to aid courts in analyzing statutory mandates and must indicate clearly the

112. Id. at $497-99$.

113. Id at 499.

114. Id at 503. Chief Judge Wright admitted that his standard requires at least a partial examination of the merits to determine jurisdiction. Id. n.21. He felt this commingling was necessary, however, to "preserve the policy of holding the courthouse door not 'wholly closed,' yet also not 'widely ajar.' " Id. (quoting Local 130, Int'1 Umion of Electrical Workers v. McCulloch, 345 F.2d 90, 97 (D.C. Cir. 1965)).

115. 642 F.2d at 503-06.

116. Id. at 512 .

117. Id. at 513 . 
jurisdictional significance of alternative forms of review. The dissent's test, however, does not successfully accomplish this task. Inquiring whether an alleged Board error involves a question of fact or statutory construction will properly allocate matters between the Board and the courts when the distinction between law and fact is clear. ${ }^{118}$ In cases that involve inseparable questions of statutory imterpretation and fact, ${ }^{119}$ however, this distinction provides little useful guidance. Arguably, such a test tends to narrow unduly the focus of a court and to obfuscate the main issues of a case. ${ }^{120}$ The usefulness of the fact-law distinction as part of a jurisdictional standard therefore is limited.

Assessing whether a statutory provision is "clear and mandatory" in creating rights for those subject to the Act also poses several difficulties as a jurisdictional mquiry. First, requiring a statutory provision to be clear is meaningless: the term clear does not distinguish statutory provisions of the Act. ${ }^{121}$ Second, the clear and mandatory standard provides imprecise guidance, for it does not aid a court in determining when to grant jurisdiction under statutory mandates. Third, this part of the dissent's test apparently allows a court's jurisdictional analysis to extend beyond the face of the Act to legislative history, 122 but it does not state whether courts should consider in their jurisdictional inquiry accepted Board practices that are not specifically approved in the Act or its legislative history. ${ }^{123}$ Fourth, if a statutory provision is ambiguous and examination of legislative history is permissible, the standard reaches a paradoxical result: an ambiguous statute is classified as clear and mandatory. ${ }^{124}$ The imprecision of the clear and mandatory standard thus may lead to arbitrary jurisdictional determinations.

118. See note 81 supra.

119. See McCormick v. Hirsch, 460 F. Supp. 1337 (M.D. Pa. 1978) (inseparable question of fact-is a parochial school an employer within meaning of section 2(2) of the Act, 29 U.S.C. $\S 152(2)(1976)$ - and statutory imterpretation-did Congress intend the Act to extend to religious institutions). See note 81 supra.

120. See Grutka v. Barbour, 549 F.2d 5, 9 (7th Cir.), cert. denied, 431 U.S. 908 (1977) (distinction between matters of law and fact required administrative adjudication of constitutional issues).

121. See Note, Labor Law: Direct Judicial Review of NLRB Election Orders, 66 Colum. L. Rev. 1546, 1551 (1966) (the difference between a clear violation of a statutory provision and any other type of a violation is illusory); $f$. Local 1545, United Blid. of Carpenters v. Vincent, 286 F.2d 127, 133 (2d Cir. 1960) ("To be sure, the distinction between violation of a clear and of a not so clear statutory command is neither completely satisfying nor . . . readily applied").

This argument assumes the term "clear" has independent meaning in this part of the jurisdictional standard.

122. One commentator suggested that legislative history must contain "an express statement ... addressing the issue involved" to satisfy the second part of the standard proposed by the Physicians dissent. See 56 Notre Dame Law. 315, 323-24 (1980).

123. Such practices imclude the contract-bar doctrine, see note 91 supra, and the blockingcharge policy, see note 97 supra.

124. See 56 Notre Dame Law. $315,323-24$ (1980). 
The third element of the dissent's test regulates the timing of judicial review based on a party's ability to secure post-election access to the courts. If a party is unable to obtain judicial review by committing an unfair labor practice, this element allows for immediate review of representation orders. ${ }^{125}$ All parties except employers can meet this requirement because the district courts represent the only effective means of access to the judiciary for these parties. ${ }^{126}$

Imitially, it would appear inappropriate to consider in a jurisdictional standard the disparity in ability to secure later judicial review of Board orders. Congress rejected arguinents premised on this consideration $^{127}$ in disapproving an amendment to the Taft-Hartley Act. ${ }^{128}$ Congress rejected these arguments, however, because the proposed amendment would have allowed immediate review of all Board representation orders, thus enabling parties to delay indefinitely a representation election by appealing these orders. ${ }^{129}$ Congress chose to prevent this practice because of the need to ensure an uninterrupted representation process. ${ }^{130}$ It is therefore consistent with Congress's intent to inquire about alternative means of judicial access in a jurisdictional standard if the standard does not allow parties to delay indefinitely a representation election.

Chief Judge Wright's test does not allow such dilatory tactics. The third part of the standard authorizes immediate judicial review of Board orders only for parties with no other ineans of access to the courts. Further, these parties must meet the other requirements of the dissent's four-part test before jurisdiction will be granted. The possible dilatory use of district court jurisdiction could be reduced further, however, by denying pre-election judicial relief to parties able to secure

125. See Physicians Nat'1 House Staff Ass'n v. Fanning, 642 F.2d 492, 512 (D.C. Cir. 1980) (en banc), cert. denied, 101 S. Ct. 1360 (1981).

126. See notes 33-54 supra and accompanying text.

127. An arguunent made in favor of the amendment was that unless it was passed, soine parties would be unable to secure judicial review of Board orders. See 93 Cong. REc. 6444 (1947) (remarks of Sen. Taft).

128. See H.R. Conf. Rep. No. 510, 80th Cong., 1st Sess. 56-57 (1947). Judge Robb, writing for the majority in Physicians Nat'l House Staff Ass'n v. Fanning, 642 F.2d 492 (D.C. Cir. 1980) (en banc), eert. denied, $101 \mathrm{~S}$. Ct. 1360 (1981) summarized the congressional hearings:

When it passed the Taft-Hartley Act, Congress considered an amendment which would have allowed immediate review of Board certification decisions. This proposal was included in the House version of the bill. ... The provision was eliminated in conference. ... Senator Taft explained this action by commenting that the proposal "would permit dilatory tactics in representation proceedings."

Id. at 499 (citations omitted).

129. See notes 24-28 supra and accompanying text.

130. See 93 CONG. REC. 6444 (1947) (remarks of Sen. Taft). 
effective post-election review by committing an unfair labor practice. ${ }^{131}$ Precluding these parties from pre-election relief imposes additional costs on thein, ${ }^{132}$ but the concoinitant benefit of significantly reducing interruptions in the representation process outweighs this hardship. ${ }^{133}$ Notwithstanding its apparent benefits, this additional jurisdictional requirement is not included in the third part of the dissent's standard.

Another aspect of the timing of judicial review not considered by the dissent's test is whether parties inust exhaust their admimistrative remedies before seeking district court relief. Requiring exhaustion of administrative remedies would allow the Board to conserve judicial time because of the structure of the Act's administrative review process. Under section 3(b) of the Act ${ }^{134}$ a regional director is delegated all powers of imitial decisionmaking. Parties to a representation proceeding can appeal his decisions to the Board. The Board then reviews the director's decisions if "compelling reasons" exist. ${ }^{135}$ Because these same reasons can provide grounds for district court jurisdiction, requiring the exhaustion of administrative reinedies allows the Board the opportumity to correct errors made by the regional director before the courts becoine imvolved.

The final element of Chief Judge Wriglit's test, which requires courts to determine whether the purposes of the Act will be thwarted by a court's exercise of jurisdiction, ${ }^{136}$ is unnecessary. If a court concludes

131. See notes 33-54 supra and accompanying text.

132. These costs arise from the necessity of a second representation campaign and from the decreased efficiency of operations resulting from workers focnsing their attention on another election rather than on their work. See Goldberg, supra note 26, at 497-98. These costs, however, are arguably negligible. Because suits to enjom representation elections usually are brought when the election campaign is almost over, employers imcur nearly identical representation campaign costs and decreases in productivity whether or not they can secure pre-election relief. See, e.g., Firestone Tire \& Rubber Co. v. Samoff, 365 F.2d 625, 626 (3d Cir. 1966). Further, pre-election suits brought by the employer can intensify employee interest in the representation election; this interest can cause a greater decrease in work productivity than would employee interest in a judicially ordered second representation election. See Goldberg, supra note 26, at 497.

133. Pre-election interruptions would be significantly reduced because the suggested jurisdictional requirement bars employers from pre-election relief, and employers have historically brought most pre-election suits. See Goldberg, supra note 26, at $493 \mathrm{n} .114$ (of the first 67 cases reported involving Kyne, 43 were filed by employers).

134. 29 U.S.C. $\S 153(b)(1976)$.

135. The "compelling reasons" are: (1) that a substantial question of law or policy is raised because of (i) the absence of, or (ii) a departure from, officially reported Board precedent; (2) that the regional director's decision on a substantial factual issue is clearly erroneous on the record and such error prejudices the rights of a party; (3) that the conduct of the hearing or any ruling made in connection with the proceeding has resulted in prejudicial error; and (4) that there are compelling reasons for reconsideration of an important Board rule or policy. 29 C.F.R. $§ 102.67$ (c) (1980).

136. If this part of the standard is intended to instruct courts when to deny pre-election jurisdiction, it is too vague to provide useful guidance. 
that the second part of the test is satisfied-that the Board acted in excess of its delegated powers-it is unlikely a court would conclude that the fourth part of the standard is met. If a court did find the last part of the test satisfied in this situation, ${ }^{137}$ it is probable the court would nevertheless grant jurisdiction. The violation of a clear and mandatory statutory provision seems to be a unore substantial ground for jurisdiction than the contravention of a general purpose of the Act. The fourth part of Chief Judge Wright's test also allows courts substantial discretion in interpreting the purposes of the Act, for the purposes are broadly defined. ${ }^{138}$ The final part of the dissent's test is therefore subject to inultifarious interpretations and does not provide precise jurisdictional guidance.

Although the Physicians dissent attempted to improve the Kyne standard, its proposed test does not adequately aid a district court in determining whether to exercise origmal jurisdiction over an alleged violation of a statutory inandate. The dissent's emphasis on whether the Board has violated a clear and mandatory statutory provision detracts from the crucial inquiry of whether the Board has acted pursuant to its discretionary authority. Chief Judge Wright's test does focus a court's inquiry on the important question of a party's ability to secure judicial review of Board representation orders by committing an unfair labor practice. Yet the dissent's standard leaves unresolved two issues related to the timing of judicial review: whether a party able to secure post-election review should be demied district court jurisdiction before the election and whether a party inust exhaust his admmistrative remedies before seeking district court relief. Although the dissent's test illustrates the need for a reformulation of the Kyne standard, it fails to resolve important questions that the Kyne exception raises.

\section{A Proposed Standard.}

A jurisdictional standard designed to replace the Kyne test should clearly identify circumstances in whicl district courts may exercise

137. A court could find both the second and fourth parts of the test satisfied if a specific statutory provision conflicted with a purpose of the Act. See Newport News Shipbuilding \& Dry Dock Co. v. NLRB, 633 F.2d 1079, 1082-83 (4th Cir. 1980) (section 7 purposes of einployee free choice and majority rule, 29 U.S.C. $\$ 157$ (1976), conficted with section $9(\mathfrak{c})(1)$ duty to investigate a decertification petition, 29 U.S.C. $\$ 159(c)(1)$ (1976)).

138. The Act states in section (1):

It is hereby declared . . . [to encourage] the practice and procedure of collective bargaining and [to protect] the exercise by workers of full freedom of association, selforganization, and designation of representatives of their own choosing, for the purpose of negotiating the terms and conditions of their employment or other mutual aid and protection.

29 U.S.C. $§ 151$ (1976). See NLRB v. Hearst Publications, Inc., 322 U.S. 111, 126 (1944). 
original jurisdiction over alleged violations of statutory mandates. Such a standard should also define the impact of alternative avenues of review on a determination of jurisdiction. Clear guidelines will reduce the likelihood of judicial infringement of Board discretion and will reduce the number of unwarranted interruptions in the representation process. To achieve these goals, a standard should permit district court jurisdiction only if: the Board has violated a nondiscretionary provision of the Act; challenging parties have exhausted their administrative remedies; and challenging parties possess no other effective means of recourse to the judiciary.

Requiring courts to determine whether the Board has violated a nondiscretionary provision of the Act recognizes the need to avoid judicial interference im areas of Board discretion and directly focuses a court's attention on that important consideration. The discretionarynondiscretionary distinction ${ }^{139}$ also provides a guideline to aid courts in analyzing statutory mandates.

Determining whether a nondiscretionary provision of the Act has been violated should involve an assessment of relevant statutory provisions and, if necessary, ${ }^{140}$ their legislative history. Additionally, courts should consider Board practices not specifically authorized by statute that have developed and become accepted over time. ${ }^{141}$ Such thorough analysis is necessary to determine when the Board is allowed to exercise its discretion and to ensure proper interpretation of statutory provisions. ${ }^{142}$

139. Essentially factual determinations would be considered discretionary under this standard. See generally 56 Notre DAME LAw. 315, 325 (1980). See note 81 supra and text accompanying note 111 supra.

140. Consideration of legislative history is usually impermissible when the statute is unambiguous. See, e.g., Wilbur v. United States, 284 U.S. 231, 237 (1931).

141. The court advocated a similar approach in National Maritime Union v. NLRB, 375 F. Supp. 421 (E.D. Pa.), affd, 506 F.2d 1052 (3d Cir. 1974), cert. denied, 421 U.S. 963 (1975). Judge Fogel, after an excellent review of the evolution of the $K y n e$ standard, stated:

From our review ... we are persuaded that the exception enunciated in the majority holding in $K y n e$ should neither be mechamically restricted to violations of "shall not" clauses of the Act, nor automatically extended to any clause which contains the word "shall" or similar language of apparently mandatory intent. Rather, it is the task of the District Court to carefully examine the provision in question, and to determine from the context, from the structure and purposes of the Act as a whole, from prior practice in the Board and decisions in the Courts, whether the terms are indeed sufficiently "clear and mandatory" to confer jurisdiction under the rule of Kyne.

375 F. Supp. at 429-30.

142. In Intertype Co. v. Penello, 269 F. Supp. 573 (W.D. Va. 1967), for example, an employer filed suit in district court to compel production of an investigation file compiled by the Board. The employer argued that the Board, by refusing to divulge the file, violated the specific mandate found in section 9(d) of the Act, 29 U.S.C. $\$ 159$ (d) (1976). Section 9(d) provides that whenever an order of the Board is based in whole or in part on facts certified following an investigation, the "certification and the record of such investigation shall be included in the transcript of the entire 
The second part of the proposed standard requires parties to exhaust their administrative remedies before seeking relief in the district courts. This requirement ensures that the Board is given the opportunity to develop fully the factual record necessary for judicial review. ${ }^{143}$ The Board also can correct errors committed by the regional directors $^{144}$ and thus reverse decisions that otherwise would provide grounds for district court jurisdiction. ${ }^{145}$

The third part of the proposed standard requires a district court to decline jurisdiction if effective ${ }^{146}$ subsequent recourse to the judiciary is available. ${ }^{147}$ Parties who could secure access to the courts through a post-election method of review, such as section $10(f), 148$ should be denied district court jurisdiction. Although this part of the standard imposes additional costs on these parties, ${ }^{149}$ the resulting reduction in the dilatory use of district court jurisdiction outweighs this burden. This

record" subject to review. Id. The court stated that "[a] literal reading of Section 9(d) would appear to support the Company's position," 269 F. Supp. at 579; it found, however, that the Board would be able to conduct effective investigations only if it preserved the confidentiality of its findings. Id. at 580. Thus, the court held that "the production of the investigation file inust rest within the sound discretion of the Board, and consequently Section 9(d) does not establish a 'specific statutory right,' the abrogation of which would be ground for this court's taking jurisdiction." Id.

143. It is generally desirable for an administrative agency to develop the factual record in order to have the benefit of the agency's expertise. See Erzatty v. Puerto Rico, 648 F.2d 770, 774 (1st Cir. 1981).

144. See notes 134-35 supra and accompanying text.

145. The exhaustion requirement can, of course, be waived when pursuit of an adininistrative remedy would be futile or when other judicially recognized exceptions to the requirement exist. See K. Davis, Administrative Law $\$ \S 20.01, .07$ (3d ed. 1972).

146. An example of an ineffective ineans of securing judicial review is that provided by section $8(b)(7)(B), 29$ U.S.C. $\$ 158(b)(7)(B)(1976)$. The section $8(b)(7)(B)$ neans of review is inadequate becanse of its speculative nature. See notes $42-54$ supra and accompanying text.

147. Thus, the third part of the suggested standard, combined with the exhaustion of administrative remedies requirement, essentially means that parties must have no other effective means available to secure district court jurisdiction. Cf. Long Island RR Co. v. United States, $193 \mathrm{~F}$. Supp. 795, 800 (E.D.N.Y. 1961) (Friendly, J.) (a district court may entertain a suit to enjoin an Interstate Commerce Commission suspension order only if the complaint shows the suspension is "plainly without statutory authority" and the aggrieved party has no other available remedy).

148. 29 U.S.C. \& 160(f) (1976). See notes 33-41 supra and accompanying text.

149. See note 132 supra and accompanying text. Intangible costs, such as the possible stignaa of initially losing a representation election, cannot be avoided by an employer under the proposed standard because an employer cannot obtain pre-election relief under this standard. A union, however, may be able to avoid these costs by enjoining an election it feels it may lose, for it can attempt to secure pre-election injunctive relief under the suggested test. This disparity in ability to prevent a representation election one might lose can be equalized. A court faced with a union suit to enjoin an election may permit the election to occur but order the Board to impound the ballots until the court passes upon the union's claim. See Goldberg, supra note 26, at 506. Several courts have adopted this solution. See, e.g., Miani Newspaper Printing Pressinen's Union v. McCullocl, 322 F.2d 993, 996 (D.C. Cir. 1963); Livingston v. McLeod, 209 F. Supp. 606, 611 (S.D.N.Y. 1962); Int'1 Prod. Union, Local 710 v. McLeod, 183 F. Supp. 790,792 (E.D.N.Y. 1960). 
portion of the suggested test therefore allows the representation process to proceed smoothly and, in combination with the other elements of the proposed standard, provides a possible solution to the probleins presented by Leedom $v$. Kyne.

\section{CONCLUSION}

The application of Leedom v. Kyne to those provisions of the Act cast in nonprohibitory terms lias led to inconsistent jurisdictional determinations. The dissent im Physicians National House Staff Association v. Fanning reformulated the Kyne standard in an attempt to eliminate this confusion. Because the dissent's standard does not accomplish this purpose, this note proposes a new standard to determine district court jurisdiction. The suggested standard allows for thorough judicial analysis of statutory provisions. It also restricts employer access to the courts prior to a representation election.

Although the proposed standard provides a possible solution to the jurisdictional problems associated with $K y n e$, it is only a partial response to the difficulties posed by judicial intervention in the representation process. Problems remain in determining what types of constitutional violations are sufficient to invoke district court jurisdiction. ${ }^{150}$ The suggested standard, however, discourages judicial encroachment into areas of decisionmaking delegated specifically to the Board and therefore may provide for more efficient resolution of labor disputes.

James F. Wyatt III

150. See notes 55-60 supra and accompanying text. 